\title{
Relevance: A Thematic Bibliographical List
}

\author{
Francisco Yus \\ University of Alicante
}

\begin{abstract}
The present volume on relevance theory contains interesting insights on both inherent aspects of the theory and possible applications to varied pragmatic interests (apparently) as distant as grammar or politeness. The following bibliography is an attempt to provide the reader with as many references on relevance theory as possible, and to carry out this attempt according to several relevance-theoretical headings grouping different objects of pragmatic research.
\end{abstract}

List of headings: (1) Pre-1986 research on relevance. (2) General comments, reviews, criticism. (3) Cognition, modularity. (4) Inference, effects/effort, context, mutual knowledge. (5) Semantics; conceptual vs. procedural meaning. (6) Explicit/implicit continuum; literalness; loose talk. (7) Grammar. (7.1) General. (7.2) Connectives. (7.3) Tense and aspect. (7.4) Mood. (7.5) Negation. (7.6) Auxiliaries (including modals); modality. (7.7) The noun phrase. (7.8) Adverbs and adverbials. (7.9) Other. (8) Literature, textual analysis, stylistics. (9) Figurative language (metaphor, metonymy, etc.). (10) Irony. (11) Humour. (12) Media discourse. (13) Music. (14) Translation. (15) Intonation, phonetics, phonology. (16) Politeness, face work. (17) Philosophy, rhetoric. (18) Speech acts, conversation, interactive particles. (19) Anthropology, ethnography, cross-cultural communication. (20) Developmental pragmatics. (21) Communication disorders and limitations. 


\section{Pre-1986 research on relevance}

Dascal, M. "Conversational relevance." Journal of Pragmatics 1 (1977): 309-328.

Gazdar, G. and D. Good. "On a notion of relevance. Comments on Sperber and Wilson's paper."

Mutual Knowledge. Ed. N.V. Smith. London: Academic Press, 1982. 88-100.

Mason, J.A. "From speech acts to conversation." Journal of Literary Semantics XI (1982): 96-103.

Moore, T. "Comments on Sperber and Wilson's paper." Mutual Knowledge. Ed. N.V. Smith.

London: Academic Press, 1982. 111-112.

Sperber, D. and D. Wilson. "Reply to Gazdar and Good." Mutual Knowledge. Ed. N.V. Smith.

London: Academic Press, 1982a. 101-110.

"Reply to Wilks." Mutual Knowledge. Ed. N.V. Smith. London: Academic Press, 1982b. 118-123.

1982c. 128-131.

. "Reply to Clark." Mutual Knowledge. Ed. N.V. Smith. London: Academic Press,

Werth, P. "The concept of "relevance' in conversational analysis." Conversation and Discourse.

Ed. P. Werth. London: Croom Helm, 1981. 129-154.

. Focus, Coherence and Emphasis. London: Croom Helm, 1984.

Wilks, Y. "Comments on Sperber and Wilson's paper." Mutual Knowledge. Ed. N.V. Smith.

London: Academic Press, 1982b. 113-117.

Wilson, D. and D. Sperber. "On Grice's theory of conversation." Conversation and Discourse. Ed.

P. Werth. London; Croom Helm, 1981. 155-178.

. "On choosing the context for utterance interpretation." Foregrounding Background.

Eds. J. Allwood and E. Hjelmquist. Doxa, 1985. 51-64.

\section{General comments, reviews, criticism}

Adler, J.E. "Comparisons with Grice." Behavioral and Brain Sciences 10 (1987): 710-711.

Akman, V. and M. Surav. "Contexts, oracles, and Relevance". AAAI-95 Workshop on "formalizing context." Boston. Internet: www.cs.bilkent.edu.tr/2akman/conf-papers/aaai/node1.html (followed by documents from ...node2.html... to node8. html), 1995.

Amel, R. "Relevance and justification." Semiotica 102 (1994): 71-88.

Austin, P. "Review of Relevance: Communication and Cognition." Australian Journal of Linguistics 7 (1987): 129-137.

Bach, K. and R.M. Harnish. "Relevant questions." Behavioral and Brain Sciences 10 (1987): 711-712.

Baclawski, K. "Relevance." Internet: www.cs.neu.edu/home/kenb/key/ltns/sectionstar3_3.html, 1996.

Berg, J. "The relevant relevance." Journal of Pragmatics 16 (1991): 411-423.

Bertuccelli-Papi, M. Qué es la pragmática. Barcelona: Paidós, 1996.

Blakemore, D. Understanding Utterances. Oxford: Blackwell, 1992.

. "Relevance theory." Handbook of Pragmatics. Eds. J. Verschueren, J.-O. Ostman and J. Blommaert. Amsterdam: John Benjamins, 1995. 443-452.

Carston, R. and S. Uchida, eds. Relevance Theory. Applications and Implications. Amsterdam: John Benjamins, 1998. 
Chametzky, R. "Pragmatics, prediction and Relevance." Journal of Pragmatics 17 (1992a): 63-72. . "Comments of Wilson's Reply." Journal of Pragmatics 17 (1992b): 79-81.

Cummings, L. "The scientific reductionism of relevance theory: The lesson from logical positivism." Journal of Pragmatics 29 (1998): 1-12.

Downes, W. Language and Society (2nd edition). Cambridge: Cambridge University Press, 1998.

Escandell Vidal, V. Introducción a la pragmática. Barcelona: Ariel, 1996.

Garnham, A. "Review of Relevance: Communication and Cognition." Journal of Literary Semantics XVI (1987): 61-63.

Gorayska, B. and R. Lindsay. "The roots of relevance." Journal of Pragmatics 19 (1993): 301-323. . "Not really a reply -more like an echo Reply to Steve Nicolle." Journal of Pragmatics 23 (1995): 683-686.

Groefsema, M., ed. Proceedings of the University of Hertfordshire Relevance Theory Workshop. Chelmsford: Peter Thomas and Associates, 1997.

Higashimori, I. and D. Wilson. "Questions on Relevance." UCL Working Papers in Linguistics 8 (1996):111-124.

"Discourse and relevance." Research Institute Reports (Kobe College) 44, 3 (1998).

Hirst, D. "Review of Relevance: Communication and Cognition." Mind \& Language 4 (1989): 138-146.

Jucker, A.H. "Review of Relevance: Communication and Cognition (2 ${ }^{\text {nd }}$ edition)." Journal of Pragmatics 27 (1997): 112-119.

Leslie, A.M. "Review of Relevance: Communication and Cognition. Mind \& Language 4 (1989): $147-150$.

Levinson, S.C. "A review of Relevance." Journal of Linguistics 25 (1989): 455-472.

Lindsay, R.O. and B. Gorayska. "On putting necessity in its place." Journal of Pragmatics 23 (1995): 343-346.

Mey, J.L. Pragmatics. An Introduction. Ox ford: Blackwell, 1994.

"On Gorayska and Lindsay's definition of relevance." Journal of Pragmatics 23 (1995): 341-342.

Mey, J.L. and M. Talbot. "Computation and the soul." Semiotica 72 (1988): 291-339.

Millikan, R.G. "What Peter thinks when he hears Mary speak." Behavioral and Brain Sciences 10 (1987): 725-726.

Morgan, J.L. and G.M. Green. "On the search for relevance." Behavioral and Brain Sciences 10 (1987): $726-727$.

Nicolle, S. "In defence of relevance theory: A belated reply to Gorayska and Lindsay, and Jucker." Journal of Pragmatics 23 (1995): 677-681.

Pateman, T. "Relevance, contextual effects and least effort." Poetics Today 7 (1986): 745-754.

Portolés, J. "Pertinencia y pragmática." Revista de Occidente 154 (1994a): 55-66.

. "Algunos comentarios sobre la teoría de la pertinencia." Pragmalingüistica 2 (1994b): 407-425.

Reboul, A. and J. Moeschler. "Faut-il continuerà faire de l'analyse de discours?" Hermes 16 (1996): 61-92.

. "Reduction and contextualization in pragmatics and discourse analysis." Linguistische Berichte 8 (1997): 283-295.

Colin, 1998.

. Contre L'analyse de Dicours. La Construction d'un Sens Commun. Paris, Armand 
Recanati, F. "Communication et cognition." Pragmalingüística 1 (1993): 281-305.

Roberts, L.D. "Relevance as an explanation of communication." Linguistics and Philosophy 14 (1991): 453-472.

Romero, E. "Relevancia, inferencia y comunicación." La Balsa de la Medusa 36 (1995): 102-111.

Rouchota, V. and A.H. Jucker, eds. Current Issues in Relevance Theory. Amsterdam: John Benjamins, 1998.

Sadock, J.M. "Remarks on the paper by Wilson and Sperber." Papers from the Parasession on Pragmatics and Grammatical Theory. Chicago Linguistic Society 22, part 2, 1986. 85-90.

Sánchez de Zavala, V. "Sobre la nueva teoría de la pertinencia." Estudios de lingüística de España

y México. Eds. V. Demonte and B. Garza Cuaron. Mexico: Universidad Nacional Autónoma de Mexico, 1990. 273-299.

Ensayos de la palabra y el pensamiento. Madrid: Trotta, 1994.

Sanders, R.E. "Review of Relevance: Communication and Cognition." Language in Society 17 (1988): 604-609.

Seuren, P. "The self-styling of Relevance Theory." Journal of Semantics 5 (1988): 123-143.

Sinclair, M. and W.W. Winckler. "Relevance theory: Explaining verbal communication." Stellenbosch Papers in Linguistics 18 (1991).

Smith, N.V. and D. Wilson. "Introduction." Lingua 87 (1992): 1-10.

Sperber, D. and D. Wilson. "Pragmatics." Cognition 10 (1981): 281-286.

. "On defining relevance." Philosophical Grounds of Rationality. Eds. R. Grandy and

R. Warner. London: Academic Press, 1982.

1995)

Relevance: Communication and Cognition. Oxford: Blackwell, 1986 (2nd edition,

. "Précis of Relevance: Communication and Cognition." Behavioral and Brain Sciences 10 (1987): $697-754$.

Relevance and Meaning. Oxford: Blackwell, forthcoming.

Toolan, M. "On relevance theory." New Departures in Linguistics. Ed. G. Wolf. New York: Garland, 1992. 146-162.

Walker, R.C.S. "Review of Relevance: Communication and Cognition." Mind \& Language 4 (1989): 151-159.

Wilks, Y. "Relevance and beliefs." Reasoning and Discourse Processes. Eds. T. Myers. K. Brown and B. McGonigle. London: Academic Press, 1986. 265-289.

"Relevance must be to someone." Behavioral and Brain Sciences 10 (1987): 735-736.

Wilks, Y. and C. Cunningham. "A purported theory of relevance." Language and Discourse: Text and Protest. Ed. J.L. Mey. Amsterdam: John Benjamins, 1986. 383-418.

Wilson, D. "Reply to Chametzky." Journal of Pragmatics 17 (1992): 73-77.

. "Relevance and understanding." Language and Understanding. Eds. G. Brown, K.

Malmkjer, A. Pollit and J. Williams. Oxford: Oxford University Press, 1994. 35-58.

Wilson, D. and D. Sperber. "Sobre la definición de relevancia." La búsqueda del significado. Ed.

L. Valdés Villanueva. Madrid: Tecnos, 1986. 583-598.

"An outline of relevance theory." Notes on Linguistics 39 (1987): 5-24.

"The self-appointment of Seuren as censor -a reply to Pieter Seuren." Journal of

Semantics 5 (1988): 145-162.

. "Outline of relevance theory." Links \& Letters 1 (1994): 85-106.

Yus, F. Pragmática y relevancia (microfiche). Alicante: Universidad de Alicante, 1996. 
Cooperación y relevancia. Dos aproximaciones pragmáticas a la interpretación.

Alicante: Universidad de Alicante, Servicio de Publicaciones, 1997.

"A decade of relevance theory." Journal of Pragmatics 30 (1998): 305-345.

Ziv, Y. "On the rationality of 'relevance' and the relevance of 'rationality." Journal of Pragmatics 12: (1988): 535-545.

\section{Cognition, modularity}

Barton, E.L. "Autonomy and modularity in a pragmatic model." CLS 25. Eds. B. Music, R. Graczyk and C. Wiltshire. Chicago: University of Chicago Press, 1989. 1-14.

Carston, R. "Language and cognition." Linguistics: The Cambridge Survey. Vol. 3: Language: Psychological and Biological Aspects. Ed. F. Newmeyer. Cambridge: Cambridge University Press, 1988. 38-68.

"Relevance-theoretic pragmatics and modularity." UCL Working Papers in Linguistics 9 (1997): 29-53.

Sinclair, M. "Fitting pragmatics into the mind: Some issues in mentalist pragmatics." Journal of Pragmatics 23 (1995): 509-539.

Wilson, D. and D. Sperber. "Pragmatics and modularity" (1986a). Pragmatics. A Reader. Ed. S. Davis. Oxford: Oxford University Press, 1991. 583-595.

\section{Inference, effects/effort, context, mutual knowledge}

Ariel, M. "Retrieving propositions from context: Why and how." Journal of Pragmatics 12 (1988): 567-600.

Brizuela, M. "The selection of definite expressions in Spanish: A note on processing effort." Paper presented at the International Cognitive Linguistics Conference. Amsterdam, July 14-19, 1997.

Clark, H.H. "The relevance of common ground: Comments on Sperber and Wilson's paper." Mutual Knowledge. Ed. N.V. Smith. London: Academic Press, 1982. 124-127.

Clark, H.H. and C.R. Marshall. "Definite reference and mutual knowledge." Elements of Discourse Understanding. Eds. A.K. Joshi, B.L. Webber and I.A. Sag. Cambridge: Cambridge University Press, 1981. 10-63.

Davies, M. "Relevance and mutual knowledge." Behavioral and Brain Sciences 10 (1987): 716-717.

Garnham, A. and J. Perner. "Does manifestness solve problems of mutuality?" Behavioral and Brain Sciences 13 (1990): 178-179.

Gerrig, R. J. "Relevance theory, mutual knowledge, and accidental irrelevance." Behavioral and Brain Sciences 10 (1987): 717-718.

Gibbs, R.W. "Mutual knowledge and the psychology of conversational inference." Journal of Pragmatics 11 (1987a): 561-588. . "The relevance of Relevance for psychological theory." Behavioral and Brain Sciences 10 (1997b): 718-719.

Giora, R. "On the informativeness requirement." Journal of Pragmatics 12 (1988): 547-565. 
Groefsema, M. "Relevance: processing implications." UCL Working Papers in Linguistics 1 (1989): 146-167.

Handley, S. and E. Buck. "Supposition, representation and relevance in human reasoning."

Proceedings of the University of Hertfordshire Relevance Theory Workshop. Chelmsford: Peter

Thomas and Associates, 1997. 90-104.

Hinkelman, E. "Relevance: Computation and coherence." Behavioral and Brain Sciences 10 (1987): 720-721.

Jaszczolt, K. "Relevance and infinity: Implications for discourse interpretation." Journal of Pragmatics 25 (1996): 703-722.

Kerkhoven, J. Mutual Understanding through Conversation: Communication as the Joint Experiential Articulation of Mutual Agency. Ph.D. Thesis. Stanford University, 1995.

Kreckel, M. Communicative Acts and Shared Knowledge in Natural Discourse. London: Academic Press, 1981.

"Communicative acts and shared knowledge: A conceptual framework and its empirical application." Semiotica 40 (1982): 45-88.

McCawley, J.D. "The multidimensionality of pragmatics." Behavioral and Brain Sciences 10 (1987): 723-724.

Macnamara, J. "Logical competence." Behavioral and Brain Sciences 10 (1987): 724-725.

Matsui, T. "Bridging reference and the notions of 'topic' and 'focus." Lingua 90 (1993a): 49-68.

"Assessing a scenario-based account of bridging reference assignment." $U C L$

Working Papers in Linguistics 5 (1993b): 211-247.

$401-436$.

"Bridging reference and style." UCL Working Papers in Linguistics 6 (1994):

"Assessing a scenario-based account of bridging reference assignment." Relevance

Theory. Applications and Implications. Eds. R. Carston and S. Uchida. Amsterdam: John Benjamins, 1998. 123-159.

Mayer, R. "The release of information in discourse: Compactness, compression, and relevance." Journal of Semantics 7 (1990): 175-219.

Moeschler, J. "Aspects pragmatiques de la référence temporelle: indétermination, ordre temporel et inférence." Languages 112 (1993): 39-54.

Murray, D. "Conversational concerns: Issues." Journal of Pragmatics 7 (1983): 1-15.

Myllyniemi, R. "Conversation as a system of social interaction." Language \& Communication 6 (1986): 147-169.

O'Neill, J. "Relevance and pragmatic inference." Theoretical Linguistics 15 (1988): 241-261.

Origgi, G. and A. Palma. "The awesome efficiency of what is false." Proceedings of the University of Hertfordshire Relevance Theory Workshop. Chelmsford: Peter Thomas and Associates, 1997. 42-46.

Pettit, P. "Inference and information." Behavioral and Brain Sciences 10 (1987): 727-729.

Politzer, G. "Characterizing spontaneous inferences." Behavioral and Brain Sciences 13 (1990): 177-178.

Ruiz de Mendoza Ibáñez, F. "Prototipos, esquemas y relevancia." Proceedings of the XI Conference of AESLA. University of Valladolid (Spain), 1995. 713-722.

Russell, S.J. "Rationality as an explanation of language?" Behavioral and Brain Sciences 10 (1987): 730-731.

Seuren, P.A.M. "How relevant?" Behavioral and Brain Sciences 10 (1987): 731-733. 
Smith, C.S. "The information needed for inference." Behavioral and Brain Sciences 10 (1987): 733-734.

Smith, N. and I. Tsimpli. "A specialist intelligence: The case of a poliglot savant." UCL Working Papers in Linguistics 5 (1993).

Sperber, D. "Understanding verbal understanding." What is Intelligence? Ed. J. Khalfa. Cambridge: Cambridge University Press, 1994. 179-198.

Sperber, D., F. Cara and V. Girotto. "Relevance theory explains the selection task." Cognition 57 (1995): 31-95.

Sperber, D. and D. Wilson. "Mutual knowledge and relevance in theories of comprehension." Mutual Knowledge. Ed. N.V. Smith. London: Academic Press, 1982a. 61-85.

."Reply to Clark." Mutual Knowledge. Ed. N.V. Smith. London: Academic Press, 1982b. 128-131.

"Reply to Gazdar and Good."Mutual Knowledge. Ed. N.V. Smith. London:

Academic Press, 1982a. 101-110.

. "Spontaneous deduction and mutual knowledge." Behavioral and Brain Sciences 13 (1990): 179-184.

Sun, Y. "Pragmatic inference and relevance theory." Waiguoyu 4 (1993): 39-43.

Tynan, J. "Procesos inferenciales en la comunicación lingüística." Proceedings of the VII Conference of AESLA. University of Seville (Spain), 1990. 565-571.

Wilson, D. "Reference and relevance." UCL Working Papers in Linguistics 4 (1992): 165-191. 197-212.

Wilson, D. and D. Sperber. "Inference and implicature." Meaning and Interpretation. Ed. C. Travis. Oxford: Blackwell, 1986b. 45-75.

Yus, F. "Pragmática del malentendido." Paper presented at the XV AESLA Conference. Zaragoza, 14-17 April 1997. To appear in I. Vázquez Orta and I. Guillén Galve (eds.), Perspectivas pragmáticas en lingüística aplicada. Zaragoza: Anúbar.

\section{Semantics; conceptual vs. procedural meaning}

Bach, K. "Semantic slack: what is said and more." Foundations of Speech Act Theory. Ed. S. Tsohatzidis. London: Routledge, 1994. 267-291.

Blakemore, D. "Linguistic constraints on pragmatic interpretation: A reassessment of linguistic semantics." Behavioral and Brain Sciences 10 (1987a): 712-713. . Semantic Constraints on Relevance. Oxford: Blackwell, $1987 \mathrm{~b}$.

."Linguistic form and pragmatic interpretation: The explicit and the implicit." The

Pragmatics of Style. Ed. L. Hickey. London: Routledge, 1989. 29-51.

. "Constraints on interpretation." Proceedings of the 16th Annual Meeting of the Berkeley Linguistics Society, 1990, 363-370.

"Restatement and exemplification." Pragmatics and Cognition 5 (1997): 1-19.

Brockway, D. "Semantic constraints on relevance." Possibilities and Limitations of Pragmatics.

Eds. H. Parret, M. Sbisà and J. Verschueren. Amsterdam: John Benjamins, 1981, 57-77.

Clark, B. "Relevance theory and the semantics of non-declaratives." Ph.D. Thesis. London: University College London, 1991. 
Escandell Vidal, V. and M. Leonetti. "Categorías funcionales y semántica procedimental." Actas del Congreso Internacional de Semántica. Universidad de La Laguna, 1997.

Espinal, M.T. "On the contribution of lexical meaning to utterance interpretation." Links \& Letters 3 (1996a): 29-38.

. "On the semantic content of lexical items within linguistic theory." Linguistics 34 (1996b): 109-131.

García González, D. "Grice, relevance and speaker's meaning." UCL Working Papers in Linguistics 5 (1993): 163-191.

Grimberg, M.L. "On Nunberg on indexicality and deixis." UCL Working Papers in Linguistics 6 (1994): 341-377.

"Against rigidity." UCL Working Papers in Linguistics 7 (1995): 49-86.

Groefsema, M. "Concepts and word meaning." Proceedings of the University of Hertfordshire Relevance Theory Workshop. Ed. M. Groefsema. Chelmsford: Peter Thomas and Associates, 1997. 57-67.

Gundel, J.K. and A.E. Mulkern. "Relevance, referring expressions, and the givenness hierarchy." Proceedings of the University of Herffordshire Relevance Theory Workshop. Ed. M. Groefsema. Chelmsford: Peter Thomas and Associates, 1997. 16-27.

Higashimori, I. "Cognition, synonymy and definitions." Euralex 1994 Proceedings (Free University of Amsterdam), 1994. 93-100.

$25-76$.

. "Concepts, polysemy and relevance theory." English Literature Review 40 (1996):

Kempson, R. "Ambiguity and the semantics-pragmatics distinction." Meaning and Interpretation.

Ed. C. Travis. Oxford: Blackwell, 1986. 77-103.

Nicolle, S. Conceptual and Procedural Encoding in Relevance Theory: A Study with Reference to English and Kiswahili. Ph.D. Thesis. University of York, 1996.

"Conceptual and procedural encoding: Criteria for the identification of linguistically

encoded procedural information." Proceedings of the University of Hertfordshire Relevance

Theory Workshop Ed. M. Groefsema. Chelmsford: Peter Thomas and Associates, 1997. 45-56.

Noguchi, R.R. "Talking and meaning in dialogue: The semantic significance of sociolinguistic codes." Journal of Literary Semantics XIII/2 (1984): 109-124.

Reboul, A. "Relevance and argumentation: How bald can you get?" Argumentation 3 (1989): 285-302.

Recanati, F. Direct Reference. From Language to Thought. Oxford: Blackwell, 1993.

Rouchota, V. "On the referential/attributive distinction." Lingua 87 (1994a): 137-167.

Smith, N.V. "On interpreting "interpretive use." Behavioral and Brain Sciences 10 (1987): 734-735.

Sperber, D. and D. Wilson. "The mapping between the mental and the public lexicon." $U C L$ Working Papers in Linguistics 9 (1997): 107-125.

Wilson, D. and D. Sperber. "Ordered entailments: An alternative to presuppositional theories."

Syntax and Semantics 11: Presupposition. Eds. C.K. Oh and D. Dineen. London: Academic Press, 1979.

"Representation and relevance." Mental Representations: The Interface between Language and Reality. Ed. R.M. Kempson. Cambridge: Cambridge University Press, 1988. 133-153. 
"Linguistic form and relevance." Lingua 90 (1993a): 1-25.

. "Pragmatique et temps." Langages 112 (1993b): 8-25.

. "Pragmatics and time." UCL Working Papers in Linguistics 5 (1993c): 277-298.

. "Pragmatics and time." Relevance Theory. Applications and Implications. Eds. R.

Carston and S. Uchida. Amsterdam: John Benjamins, 1998. 1-22.

Ying, I. "Multiple constraints on processing ambiguous sentences: Evidence from adult L2 learners." Language Learning, forthcoming.

Ziv, Y. "KAZE as discourse marker and lexical hedge: Conceptual and procedural properties." Paper presented at the IPRA Conference in Mexico, 1997.

\section{Explicit/implicit continuum; literalness; loose talk}

Bach, K. "Conversational impliciture." Mind \& Language 9 (1994): 124-162.

. "Semantic slack. What is said and more." Foundations of Speech Act Theory. Ed.

S.L. Tsohatzidis. London, Routledge, 1994b. 267-291.

Bertuccelli-Papi, M. "Implicit meaning between implicature and explicature." Lo spazio della conversazione. Eds. A. Johnson et al. Pisa, 1993.

"Insinuating. The seduction of unsaying." Pragmatics 6 (1996): 191-203.

Carston, R. "Saying and implicating." Paper read at the Cumberland Lodge Conference on Logical Form, 1985.

. "Being explicit." Behavioral and Brain Sciences 10 (1987): 713-714.

"Implicature, explicature, and truth-theoretic semantics." Mental Representations:

The Interface between Language and Reality. Ed. R.M. Kempson. Cambridge: Cambridge University Press, 1988, 155-181.

$2(1990): 1-31$.

"Quantity maxims and generalised implicature." UCL Working Papers in Linguistics

. "Enrichment and loosening: Complementary processes in deriving the proposition expressed." UCL Working Papers in Linguistics 8 (1996): 61-88.

. "Informativeness, relevance and scalar implicature." Relevance Theory. Applications and Implications. Eds. R. Carston and S. Uchida. Amsterdam: John Benjamins, 1998. 179-236.

. Pragmatics and the Explicit/Implicit Distinction. Oxford: Blackwell, forthcoming. Dogan, G. The Pragmatics and Indirectness of Meaning: A Relevance-Theoretic Approach to Epigrams and Graffiti in Turkish. Ph.D. Manchester: University of Manchester, 1992.

Franken, N. "Vagueness and approximation in relevance theory." Journal of Pragmatics 28 (1997): 135-151.

Groefsema, M. "'Can you pass the salt?': A short-circuited implicature?" Lingua 87 (1992): 103-135.

Itani, R. "Explicature and explicit attitude." UCL Working Papers in Linguistics 4 (1992). "What is the literal meaning of a sentence?" Links \& Letters 3 (1996): 39-48.

Kandolf, C. "On the difference between explicatures and implicatures in relevance theory." Nordic Journal of Linguistics 16 (1993): 33-46.

Leonetti, M. Implicaturas generalizadas y relevancia. Revista Española de Lingǘstica 23 (1993): 107-139. 
Levinson, S.C. "Implicature explicated?" Behavioral and Brain Sciences 10 (1987a): 722-723.

"Minimization and conversational inference." The Pragmatic Perspective. Eds. J.

Verschueren and M. Bertuccelli-Papi. Amsterdam: John Benjamins, 1987b. 61-129.

Recanati, F. "Literalness and other pragmatic principles." Behavioral and Brain Sciences 10 (1987): 729-730.

. "The pragmatics of what is said." Pragmatics. A Reader. Ed. S. Davis. Oxford:

Oxford University Press, 1991. 97-120.

"The alleged priority of literal interpretation." Cognitive Science 19 (1995): 207-232.

Ruiz de Mendoza Ibáñez, F. "Implicatures, explicatures and conceptual mappings." Paper read at the First Aelico Conference. University of Alicante (Spain), May 1998.

Sperber, D. and D. Wilson. "Loose talk." Pragmatics. A Reader. Ed. S. Davis. Oxford: Oxford University Press, 1991. 540-549.

Vicente, B. "Non-literal speech and indirection." Paper presented at the International Pragmatics Conference, Mexico City, 1996.

. "La demarcación de lo explícito y lo implícito." Investigaciones sobre el Lenguaje en

Honor de Víctor Sánchez de Zavala. Ed. K. Korta and F. García Murga. U.P.V., forthcoming.

Yus, F. "Indirectmess in conversation. The theory of sub-continua." Paper presented at the XXI International AEDEAN Conference. Seville, 18 December 1997.

\section{Grammar}

\subsection{General}

Haegeman, L. "Relevance theory and the scope of grammar." Behavioral and Brain Sciences 10 (1987): 719-720.

Higashimori, I. "Review article: Mental Representations: The Interface between Language and Reality." English Linguistics 9 (1992): 335-356.

Kempson, R. "Ambiguity and the semantics-pragmatics distinction." Meaning and Interpretation.

Ed. C. Travis. Oxford: Blackwell, 1986. 77-103.

. "Grammars as input systems." Behavioral and Brain Sciences 10 (1987a): 721-722.

"Grammar and conversational principles." Cambridge Linguistic Survey. Vol. 2. Ed.

F. Newmeyer. Cambridge: Cambridge University Press, 1987b. 139-163.

. "On the grammar-cognition interface: The Principle of Full Interpretation." Mental

Representations: The Interface Between Language and Reality. Ed. R.M. Kempson. Cambridge: Cambridge University Press, 1988a. 199-224.

"Logical form: The grammar-cognition interface." Journal of Linguistics 24 (1988b): 393-431.

Nicolle, S. "A relevance-theoretic perspective on grammaticalization." Cognitive Linguistics (in press).

Stainton, R.J. "Using non-sentences: An application of relevance theory." Pragmatics and Cognition 2 (1994): 269-284. 


\subsection{Connectives}

Blakemore, D. "So' as a constraint on relevance." Mental Representations: The Interface between Language and Reality. Ed. R.M. Kempson. Cambridge: Cambridge University Press, 1988a, $28-51$.

"The organization of discourse." Linguistics: The Cambridge Survey. Vol 4. Ed. F. Newmeyer. Cambridge: Cambridge University Press, 1988b, 229-250.

"Denial and contrast: A relevance theoretic analysis of but." Linguistics and Philosophy 12 (1989): 15-37.

Blass, R. Discourse Connectivity and Constraints on Relevance in Sissala. Ph.D. Thesis. University of London, 1988.

229-236.

"Grammaticalisation of interpretive use: the case of $r \varepsilon$ in Sissala." Lingua 79 (1989):

Relevance Relations in Discourse. Cambridge: Cambridge University Press, 1990.

"Are there logical relations in a text?" Lingua 90 (1993): 91-110.

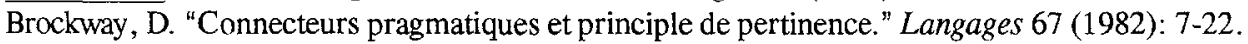

Carston, R. "Conjunction, explanation and relevance." Lingua 90 (1993): 27-48.

. "Conjunction and pragmatic effects." The Encyclopedia of Language and Linguistics.

Ed. R. Asher. Oxford: Pergamon, 1994. 692-698.

Eniko, N.T. "On the role of pragmatic connectives in Hungarian spoken discourses." Organization in Discourse (Anglicana Turkuensia 14). Eds. B.-S. Warvick and R. Tanskanen. Turku: University of Turku, 1995. 393-403.

Franken, N. "La theorie de la pertinence et les connecteurs: vers une description procedurale de puisque." Orbis Linguarum 6 (1997): 189-198.

Garrido, J. "Operadores epistémicos y conectores textuales." Aproximaciones pragmalingüísticas al español. Eds. H. Haverkate, K. Hengeveld and G. Mulder. Amsterdam: Rodopi, 1993.

Gutt, E.-A. "Towards an analysis of pragmatic connectives in Silt'i.'" Proceedings of the Eighth International Conference of Ethiopian Studies. 26-30 November 1984. vol. 1. Addis Ababa University: ELM Publications, 1988.

Haegeman, L. "The Interpretation of the Particle da in West Flemish." Lingua 90 (1993): 111-128. Higashimori, I. "BUT/YET/STILL and relevance theory." Papers Presented to Professor Yoshimitsu Narita on the Occasion His Sixtieth Birthday. Tokyo: Eihosha, 1992. 333-354.

. "Except, but and relevance theory." English Literature Review 36 (1992a): 62-108. "A relevance-theoretic analysis of EVEN, SAE / SURA / MO / TEMO / DEMO / DATTE / MADE." English Literature Review 38 (1995a): 51-80.

"Correlation of discourse connectives: A relevance-theoretic account." English Literature Review 39 (1995b): 48-88.

. "A combinatory dictionary of English discourse connectives: Based on relevance theory. Euralex '96 Proceedings. University of Goteborg, Sweden, 1996.223-236.

. "EVEN,SAE / SURA / MO as constraints on contextual assumptions." Discourse and Perspectives in Cognitive Linguistics (Current Issues in Linguistic Theory 15I). Eds. W.-A. Liebert et al. Amsterdam: John Benjamins, 1997.

Itani, R. "Japanese conjunction kedo ('but') in utterance-final use: A relevance-based analysis." English Linguistics 9 (1992a): 265-283. 
. "Japanese sentence-final particle ne: a relevance-theoretic approach." UCL Working Papers in Linguistics 4 (1992b).

"The Japanese sentence-final particle $k a$ : A relevance-theoretic approach." Lingua $90(1993): 129-147$.

Iten, C. "Because and although: A case of duality?" UCL Working Papers in Linguistics 9 (1997): $55-76$.

Luscher, J. "Connecteurs et marques de pertinence: l'exemple de d'ailleurs." Cahiers de Linguistique Française 10 (1989): 101-145.

Luscher, J.M. and J. Moeschler. "Approches dèrivationnelles et procédurales des opérateurs et connecteurs temporels: les exemples de et et de enfin." Cahiers de Linguistique Française 11 (1990): 77-104.

Moeschler, J. "Pragmatic connectives, argumentative coherence and relevance." Argumentation 3 (1989a): 321-339.

Hermès, $1989 \mathrm{~b}$.

Modélisation du Dialogue. Représentation de L'inference Argumentative. Paris:

"Relevance and conversation." Lingua 90 (1993): 149-171.

Montolio Durán, E. "La teoría de la relevancia y el estudio de los conectores discursivos." Introducción a la Pragmática Lingǘistica. Ed. C. Fuentes Rodríguez. Sevilla: Universidad de Sevilla, 1997. 27-40.

Nolke, H. "Pertinence et modalisateurs d'enonciation." Cahiers de Linguistique Française 11 (1990).

Portolés, J. "La distinción entre los conectores y otros marcadores del discurso en español." Verba 20 (1993): 141-170.

. "Sobre la organización interna de las intervenciones." Pragmática y gramática del español hablado. Eds. A. Briz et. al. Valencia: Universidad de Valencia/Libros Pórtico, 1997. 203-214.

Rosales Sequeiros, X. "Discourse relations, coherence and temporal relations." UCL Working Papers in Linguistics 7 (1995): 177-195.

Rouchota, V. "But: Contradiction and relevance." UCL Working Papers in Linguistics 2 (1990): 441-475.

. "Discourse connectives: What do they link?" UCL Working Papers in Linguistics 8 (1996): 199-212.

. "Connectives, coherence and relevance." Current Issues in Relevance Theory. Eds.

V. Rouchota and A. Jucker. Amsterdam: John Benjamins, 1998. 11-58.

Serra i Alegre, E. "El valor comunicativo de la conjunción copulativa." Pragmática y gramática del español hablado. Eds. A. Briz et. al. Valencia: Universidad de Valencia/Libros Pórtico, 1997. 395-399.

Takeuchi, M. "Conceptual and procedurat encoding: Cause-consequence conjunctive particles in Japanese." UCL Working Papers in Linguistics 9 (1997): 127-148.

Unger, C.J. "The scope of discourse connectives: Implications for discourse organization." Journal of Linguistics 32 (1996): 403-438.

Vandepitte, S. Every Why Has a Wherefore: A Generative-Pragmatic Study of the Expression and Interpretation of Causality in Modern Spoken British English, with Particular Reference to Conjuncts and Conjunctions. Ph.D. Thesis. Rijksuniversiteit te Gent, Belgium, 1990. 


\subsection{Tense and aspect}

Moeschler, J. "Aspects pragmatiques de la réference temporelle: Indétermination, ordre temporel et inférence." Languages 112 (1993b): 39-54.

"Ordre temporel, narration et analyse de discours." Cahiers de Linguistique Francaise 18 (1996): 299-328.

Le Temps des Événements. Une Approche Pragmatique du Temps et de L'aspect. Paris: Kimé, forthcoming.

Smith, N.V. "Observations on the pragmatics of tense." UCL Working Papers in Linguistics 2 (1990): 82-94.

Žegarac, V. "Relevance theory and the meaning of the English progressive." UCL Working Papers in Linguistics 1 (1989): 19-29. $113-143$.

"Pragmatics and verbal aspect." UCL Working Papers in Linguistics 2 (1990):

"Some observations on the pragmatics of the progressive." Lingua 90 (1993): 201-220.

Ziv, Y. "Relevance Theory and Extraposed Relative Clauses." Proceedings of the University of Hertfordshire Relevance Theory Workshop. Ed. M. Groefsema. Chelmsford: Peter Thomas and Associates, 1997. 112-119.

\subsection{Mood}

Clark, B. "A relevance-based approach to pseudo-imperatives." UCL Working Papers in Linguistics 1 (1989): 53-74.

. Relevance Theory and the Semantics of Non-Declaratives. Ph.D. Thesis. University College London, 1991.

$79-121$.

"Relevance and 'pseudo-imperatives." Linguistics and Philosophy 16 (1993a):

"Let and let's: Procedural encoding and explicature." Lingua 90 (1993b): 173-200.

Lunn, P. "The Spanish subjunctive and relevance." Studies in Romance Linguistics. Eds. C. Kirschner and J. de Cesaris. Amsterdam: John Benjamins, 1989. 249-260.

Rouchota, V. The Semantics and Pragmatics of the Subjunctive in Modern Greek-A RelevanceTheoretic Approach. Ph.D. thesis. University of London, 1994a.

."The subjunctive in Modern Greek: Dividing the labour between semantics and pragmatics." Journal of Modern Greek Studies 12 (1994b): 185-201.

"Na-interrogatives in Modern Greek: Their interpretation and relevance." Themes in Greek Linguistics. Papers from the 1st International Conference on Greek Linguistics. Eds. I. Philippaki-Warburton, K. Nicolaides and M. Sifianou. Amsterdam: John Benjamins, 1994c. 177-184.

Wilson, D. and D. Sperber. "Mood and the analysis of non-declarative sentences." Human Agency: Language, Duty and Value. Eds. J. Dancy, J. Moravcsik and C. Taylor. Stanford, C.A.: Stanford University Press, 1988. 77-101. 


\subsection{Negation}

Carston, R. "Metalinguistic negation and echoic use." UCL Working Papers in Linguistics 6 (1994): 321-339.

. "Metalinguistic negation and echoic use." Journal of Pragmatics 25 (1996): 309-330.

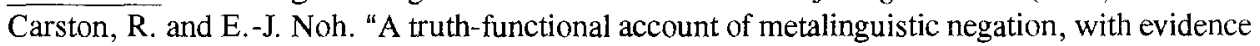
from Korean." UCL Working Papers in Linguistics 7 (1995), 1-26.

Fretheim, T. "A pragmaticization process affecting Norwegian negatives with scalar expressions." Proceedings of the University of Hertfordshire Relevance Theory Workshop. Ed. M. Groefsema. Chelmsford: Peter Thomas and Associates, 1997. 4-15.

Moeschler, J. "The pragmatic aspects of linguistic negation: Speech act, argumentation and pragmatic inference." Argumentation 6 (1991): 51-75.

Wescoat, M. and A. Yoshimura. "Negative polarity phenomena in adversative constructions." Osaka University Papers in English Linguistics (Eds. S. Kawakami, Y. Oba and M.T. Wescoat) 2 (1995): 211-222

Yoshimura, A. "The cognitive structure of negation as an NPI-licensing condition." English Linguistics 9 (1992): 244-264.

. "Pragmatic and cognitive aspects of negative polarity." Osaka University Papers in English Linguistics (Eds. S. Kawakami and M.T. Wescoat) 1 (1993): 141-173.

. "A cognitive constraint on negative polarity phenomena." Proceedings of the Twentieth Annual Meeting of the Berkeley Linguistics Society 20 (1994): 599-610.

"Negative polarity in comparatives: The need for contrastive assumptions." Foreign Linguistic and Literary Studies 33 (1996): 153-173.

. "Procedural semantics and metalinguistic negation." Relevance Theory: Applications and Implications. Eds. R. Carston and S. Uchida. Amsterdam: John Benjamins, 1997. 105-122.

7.6. Auxiliaries (including modals); modality.

Berbeira Gardón, J.L. "Posibilidad epistémica, posibilidad radical y pertinencia." Pragmalingüiśstica 1 (1993): 53-78.

"Scope-ambiguity, modal verbs and quantification." Estudios Ingleses de la Universidad Complutense 4 (1996a): 53-66. . Los Verbos Modales Ingleses. Estudio Semántico-Pragmático. Cadiz: Servicio de Publicaciones, 1996b. 223-240.

"Epistemic modality and discourse connectivity." Pragmalingüística 3-4 (1997):

Carretero Lapeyre, $\mathbf{M}$. "The relevance of politeness in the epistemic interpretation of the English modals." Pragmalingüistica 3-4 (1997): 241-259.

Groefsema, M. "Can, may, must and should: A relevance-theoretic account." Journal of Linguistics 31 (1995): 53-79.

Haegeman, L. "Be going to and will: A pragmatic account." Journal of Linguistics 25 (1989): 291-319.

Klinge, A. "The English modal auxiliaries: From lexical semantics to utterance interpretation." Journal of Linguistics 29 (1993): 315-357. 
. "On the linguistic interpretation of contractual modalities." Journal of Pragmatics 23 (1995): 649-675.

Nicolle, S. "Relevance and the effect of modal auxiliaries in logical reasoning tasks." The Role of Pragmatics in Contemporary Philosophy: Papers of the 20th International Wittgenstein Symposium. Eds. P. Weingartner, G. Schurz and G. Dorn. Vol 2: 721-727.

355-377.

Papafragou, A. "Modality in language development: A reconsideration of the evidence." UCL Working Papers in Linguistics 9 (1997): 77-105.

"Modality and semantic underdeterminacy." Current Issues in Relevance Theory.

Eds. V. Rouchota and A. Jucker. Amsterdam: John Benjamins, 1998. 237-270.

\subsection{The noun phrase}

Breheny, R. "A unitary approach to the interpretation of definites." UCL Working Papers in Linguistics 9 (1997): 1-27.

Figueras Solanilla, C. "Semántica y pragmática de las expresiones referenciales: anáfora, referencia y relevancia." Paper read at the First Aelico Conference. University of Alicante (Spain), May 1998.

Foster-Cohen, S.H. "Exploring the boundary between syntax and pragmatics: Relevance and the binding of pronouns. "Journal of Child Language 21 (1994): 237-255.

Gundel, J.K. "Relevance theory meets the givenness hierarchy: An account of inferrables." Reference and Referent Accessibility. Eds. T. Fretheim and J.K. Gundel. Amsterdam: John Benjamins, forthcoming.

Jucker, A. "Pragmatics of the definite article in English." Pragmatic Grammar Components. Ed.

F.J.H. Dols. Tilburg: Tilburg University Press, 1992. 117-133.

Kleiber, G. "Article defini: Unicite et pertinence." Revue Romane 27 (1992): 61-89.

Leonetti, M. "El artículo definido y la construcción del contexto." Signo y Seña 5 (1996): 103-138. "A relevance-theoretic account of the property predication restriction." Current Issues in Relevance Theory. Eds. V. Rouchota and A. Jucker. Amsterdam: John Benjamins, 1998. 141-168.

Papafragou, A. "On generics." UCL Working Papers in Linguistics 8 (1996): 165-198.

Rouchota, V. "On indefinite descriptions." Journal of Linguistics 30 (1994b): 441-475.

Taylor, J.R. "Possessives and relevance." Papers in Linguistics. Eds. R.P. Botha et al. University of Stellenbosch, 1993.

\subsection{Adverbs and adverbials}

Bertuccelli-Papi, M. "Determining the proposition expressed by an utterance: The role of 'domain adverbs." Textus V (1992): 123-140.

. "Semantic vagueness and degree of precision adverbs." Textus VII (1996): 313-332.

Espinal, M.T. "The representation of disjunct constituents." Language 67 (1991): 726-762.

Ifantidou-Trouki, E. "Sentential adverbs and relevance." Lingua 90 (1993): 69-90.

Jucker, A. "The discourse marker well: A relevance-theoretical account. "Journal of Pragmatics 19 (1993): 435-452. 
Tanaka, K. "The Japanese adverbial Yahari or Yappari." Relevance Theory. Applications and Implications. Eds. R. Carston and S. Uchida. Amsterdam: John Benjamins, 1998. 23-46.

Watts, R.J. "Relevance in conversational moves: A reappraisal of "well." Studia Anglica Posnaniensia 19 (1986): 37-59.

"A relevance-theoretic approach to commentary pragmatic markers: The case of actually, really and basically." Acta Linguistica Hungarica 38 (1988): 235-260.

"Taking the pitcher to the 'well.' Native speakers' perception of their use of discourse markers in conversation." Journal of Pragmatics 13 (1989): 203-237.

\subsection{Other}

Blakemore, D. "Echo questions: A pragmatic account." Lingua 94 (1994): 197-211.

Breheny, R. "Pro-active forms." UCL Working Papers in Linguistics 8 (1996): 21-60.

"Interface economy and focus." Current Issues in Relevance Theory. Eds. V.

Rouchota and A. Jucker. Amsterdam: John Benjamins, 1998. 105-140.

Escandell Vidal, V. "Sintaxis y uso interpretativo." Investigaciones sobre el Lenguaje en Honor de Víctor Sánchez de Zavala. Ed. K. Korta and F. García Murga. U.P.V., forthcoming.

Jucker, A.H. "The relevance of cleft constructions." Multilingua 16 (1997): 187-198.

König, E. The Meaning of Focus Particles: A Comparative Perspective. London: Routledge, 1991. König, E. and S. Requardt. "A relevance-theoretic approach to the analysis of modal particles in German." Multilingua 10 (1991): 63-77.

Montolío, E. “'Si me lo permiten....' Gramática y pragmática: sobre algunas estructuras condicionales regulativas en español.." Aproximaciones pragmalingüísticas al español. Eds. H. Haverkate, K. Hengeveld and G. Mulder. Amsterdam: Rodopi, 1993.

Noh, E.-J. "A pragmatic approach to echo questions." UCL Working Papers in Linguistics 7 (1995): 107-140.

. "A relevance-theoretic account of metarepresentative uses in conditionals." UCL Working Papers in Linguistics 8 (1996): 125-163.

Rouchota, V. "The interpretation of na-clauses in Modern Greek: A relevance-theoretic approach." Ucl Working Papers in Linguistics 3 (1991).

Rubovitz, T. "The relevance of relevance theory to syntactic phenomena: Relevance theory and extraction from relative clauses." Proceedings of the University of Hertfordshire Relevance Theory Workshop. Ed. M. Groefsema. Chelmsford: Peter Thomas and Associates, 1997. $120-130$.

Smith, N.V. "Can pragmatics fix parameters?" UCL Working Papers in Linguistics 1 (1989): $169-179$.

. "On interpreting conditionals." Australasian Journal of Linguistics 3 (1983): 1-24.

Smith, N.V. and A. Smith. "A relevance-theoretic account of conditionals." Language, Speech and Mind: Essays in Honor of Victoria Fromkin. Eds. L. Hyman and C. Li. London: Routledge, 1988. 322-352.

Stainton, R. "Using non-sentences: An application of Relevance Theory." Pragmatics \& Cognition 2 (1994): 269-284.

Uchida, S. "Immediate contexts and reported speech." UCL Working Papers in Linguistics 9 (1997): 149-175. 
Vackov, V. "'Free' word order and relevance: from Prague to London or to London from Prague. Oxford Working Papers in Philology, Phonetics and Linguistics 2 (1997): 119-135.

\section{Literature, textual analysis, stylistics}

Bertuccelli-Papi, M. "On the relationship between sentence themes and text topics." Studi Italiani di Linguistica Teorica e Applicata, 1994. 127-140.

Bex, T. Variety in Written English. Texts in Society: Societies in Text. London: Routledge, 1996.

Blakemore, D. "The relevance of reformulations." Language and Literature 2 (1993): 101-120.

"Relevance, poetic effects and social goals: A reply to Culpeper." Language and Literature 3 (1994): 49-59.

Blass, R. "Cohesion, coherence and relevance." Notes on Linguistics 34 (1986): 41-64.

Borthen, K., T. Fretheim, and R.A. Nilsen. "Ellipsis and inference." Proceedings of the University of Hertfordshire Relevance Theory Workshop. Ed. M. Groefsema. Chelmsford: Peter Thomas and Associates, 1997. 78-89.

Burton-Roberts, N. "Utterance, relevance and problems with text grammar." Australian Journal of Linguistics 5 (1985): 285-296.

Charolles, M. "Cohesion, coherence et pertinence du discours." Revue Internationale de Linguistique Francaise 29 (1994): 125-151.

Clark, B. "Stylistic analysis and relevance theory." Language and Literature 5 (1996): 163-178.

Clark, H.H. "Relevance to what?" Behavioral and Brain Sciences 10 (1987): 714-715.

Culpeper, J. "Why relevance theory does not explain 'the relevance of reformulations." Language and Literature 3 (1994): 43-48.

Escandell Vidal, V. "La noción de estilo en la teoría de la relevancia." Foro Hispánico 8 (1995): 55-64.

Furlong, A. Relevance Theory and Literary Interpretation. Ph.D. Thesis. University of London, 1996.

Giora, R. "A text-based analysis of non-narrative texts." Theoretical Linguistics 12 (1985): 115-135.

"Discourse coherence and theory of relevance: Stumbling blocks in search of a unified theory." Journal of Pragmatics 27 (1997): 17-34.

"Discourse coherence is an independent notion: A reply to Deirdre Wilson." Journal of Pragmatics 29 (1998): 75-86.

Green, K. "Relevance theory and the literary text: Some problems and perspectives." Journal of Literary Semantics XXII (1993): 207-217.

. "Butterflies, wheels and the search for literary relevance." Language and Literature. forthcoming.

Groefsema, M. "Understood arguments: A semantic/pragmatic approach." Lingua 96 (1995): 139-161.

Kreml, N. Relevance, Textual Unity, and Politeness in Writing about Science. Ph.D. thesis. University of South Carolina, 1992.

Mackenzie, I. "Relevance and writing." Journal of Literary Semantics XXIV (1995): 104-116.

MacMahon, B. "Indirectness, rhetoric and interpretive use: Communicative strategies in Browning's My Last Duchess." Language and Literature 5 (1996): 209-223. 
Pilkington, A. "The literary reading process: A relevance theory perspective." Empirical Studies of Literature: Proceedings of the Second IGEL Conference. Eds. E. Ibsch, D. Schram and G. Steen. Amsterdam: Rodopi, 1991a. 117-123. . "Poetic effects: A relevance theory perspective." Literary Pragmatics. Ed. R. Sell. London: Routledge, 1991b. 44-61. . "Poetic effects." Lingua 87 (1992): 29-51. Poetic Thoughts and Poetic Effects. Ph.D. thesis. University of London, 1994. "Introduction: Relevance theory and literary style." Language and Literature 5 (1996).

Pilkington, A., B. MacMahon and B. Clark. "Looking for an argument: A response to Green." Language and Literature 6 (1997): 139-148.

Reboul, A. "The relevance of Relevance for fiction." Behavioral and Brain Sciences 10 (1987): 729. 1992. Rhétorique et Stylistique de la Fiction. Nancy: Presses Universitaires de Nancy,

Richards, C. "Inferential pragmatics and the literary text." Journal of Pragmatics 9 (1985): 261-285.

Rosales Sequeiros, X. "Discourse relations, coherence and temporal relations." UCL Working Papers in Linguistics 7 (1995): 177-195.

Schwarze, C. "Text understanding and lexical knowledge." The Pragmatic Perspective. Eds. J. Verschueren and M. Bertuccelli-Papi. Amsterdam: John Benjamins, 1987. 587-612.

Seung, T.K. "Pragmatic context and textual interpretation." Journal of Literary Semantics II (1980): 82-93.

Trotter, D. "Analysing literary prose: The relevance of relevance theory." Lingua 87 (1992): 11-27.

Uchida, S. "Text and relevance." Relevance Theory. Applications and Implications. Eds. R. Carston and S. Uchida. Amsterdam: John Benjamins, 1998. 161-178.

Unger, C.J. "The scope of discourse connectives: Implications for discourse organization." Journal of Linguistics 32 (1996): 403-438.

Varela Bravo, E.J. "Relevancia: Ventajas de este enfoque pragmático para el estudio de textos anglosajones ejemplificado en The Wanderer." Actas del XII Congreso de AESLA. Alicante (Spain), 1988. 261-266.

"Relevance and irony: A pragmatic reading of a passage from W. Kennedy: Ironweed." Babel Afial 63 (1993).

"Faulty logic and love affairs: A pragmatic interpretation of a passage from Julian Barnes' Talking it Over." Atlantis XVIII (1996): 416-432.

Wilson, D. "Truth, coherence and relevance." Paper presented at the Osaka Conference on Relevance, 1993.

"Discourse, coherence and relevance: A reply to Rachel Giora." Journal of Pragmatics 29 (1998): 57-74.

Yus, F. "The 'what-do-you-mean syndrome.' A taxonomy of misunderstandings in Harold Pinter's plays." Estudios Ingleses de la Universidad Complutense 6 (1998), in press. 


\section{Figurative language (metaphor, metonymy, etc.)}

Furlong, A. "Towards an inferential account of metonymy." UCL Working Papers in Linguistics 1 (1989): 136-144.

Gibbs, R.W. The Poetics of Mind: Figurative Thought, Language and Understanding. Cambridge: Cambridge University Press, 1994.

Goatly, A. "Register and the redemption of relevance theory. The case of metaphor." Pragmatics 4 (1994): 139-181.

Higashimori, I. "Metonymy understanding and relevance theory." Annual Bulletin of Research Institute for Social Science 26 (1996): 61-86.

. "Metonymic meaning change and relevance." Research Institute Reports (Kobe College) 44, 2 (1997).

Papafragou, A. "Metonymy and relevance." UCL Working Papers in Linguistics 7 (1995a): 141175.

. "The comprehension of metonymy." Paper presented at the Autumn Meeting of the $L A G B$. University of Essex, 1995b.

"Figurative language and the semantics-pragmatics distinction." Language and Literature 5 (1996a). . "On metonymy." Lingua 99 (1996b): 169-195.

Pilkington, A. "A relevance theoretic view of metaphor." Parlance 2 (1990): 102-117.

Song, N.S. "Metaphor and metonymy." Relevance Theory. Applications and Implications. Eds. R. Carston and S. Uchida. Amsterdam: John Benjamins, 1998. 87-104.

Vicente, B. "Metaphor, meaning and comprehension." Pragmatics 2 (1992): 49-62. . Mecanismos semántico-pragmáticos en el análisis de la metáfora. Universidad del País Vasco, Servicio de Publicaciones, 1995.

. "On the semantics and pragmatics of metaphor: Coming full circle." Language and Literature 5 (1996).

Yoshimura, A. "Explicature and implicature formation in the modeling of metaphor and metonymy." Osaka University Papers in English Linguistics I (1993): 175-184.

\section{Irony}

Franken, N. "L'ironie dans la theorie de la pertinence." Orbis Linguarum 5 (1996): 223-230.

. "L'ironie: essai de description dans la théorie de la pertinence." Orbis Linguarum (forthcoming).

Hamamoto, H. "Irony from a cognitive perspective." Relevance Theory. Applications and Implications. Eds. R. Carston and S. Uchida. Amsterdam: John Benjamins, 1998. 257-270.

Hymes, D.H. "A theory of verbal irony and a Chinookan pattern of verbal exchange." The Pragmatic Perspective. Eds. J. Verschueren and M. Bertuccelli-Papi. Amsterdam: John Benjamins, 1987. 293-337.

Kreuz, R.J. and S. Glucksberg. "How to be sarcastic: the echoic reminder theory of verbal irony." Journal of Experimental Psychology: General 118 (1989): 374-386.

Mariscal Chicano, J.M. "Distintos análisis de la oposición irónica." Pragmalingüística 1 (1993): 187-209. 
. “Quién finge la ironía pertinente?” Pragmalingüística 2 (1994): 319-356.

Martin, R. "Irony and universe of belief." Lingua 87 (1992): 77-90.

Seto, K. "On non-echoic irony." Relevance Theory. Applications and Implications. Eds. R. Carston and S. Uchida. Amsterdam: John Benjamins, 1998. 239-255.

Sperber, D. "Verbal irony: Pretense or echoic mention?" Journal of Experimental Psychology: General 113 (1984): 130-136.

Sperber, D. and D. Wilson, 1981. "Irony and the use-mention distinction." Pragmatics. A Reader, Ed. S. Davis. Oxford: Oxford University Press, 1991. 550-563.

"Irony and relevance: A reply to Seto, Hamamoto and Yamanashi." Relevance

Theory. Applications and Implications. Eds. R. Carston and S. Uchida. Amsterdam: John Benjamins, 1998. 283-293.

Varela Bravo, E.J. "Relevance and irony: A pragmatic reading of a passage from W. Kennedy: Ironweed." Babel Afial 63 (1993).

Wilson, D. and D. Sperber. "On verbal irony." Lingua 87 (1992): 53-76.

Yamanashi, M. "Some issues in the treatment of irony and related tropes." Relevance Theory. Applications and Implications. Eds. R. Carston and S. Uchida. Amsterdam: John Benjamins, 1998. 271-281.

Yus, F. "Irony: Context accessibility and processing effort." Pragmalingüistica 5 (1998).

\section{Humour}

Curcó, C. "Some observations on the pragmatics of humorous interpretations. A relevancetheoretic approach." UCL Working Papers in Linguistics 7 (1995): 27-47

. "The implicit expression of attitudes, mutual manifestness and verbal humour." UCL Working Papers in Linguistics 8 (1996): 89-99.

"Relevance and the manipulation of the incongruous: Some explorations of verbal humour." Proceedings of the University of Hertfordshire Relevance Theory Workshop. Ed. M. Groefsema. Chelmsford: Peter Thomas and Associates, 1997. 68-72.

. "Indirect echoes and verbal humour." Current Issues in Relevance Theory. Eds. V.

Rouchota and A. Jucker. Amsterdam: John Benjamins, 1998. 305-326.

Jodlowiec, M. The Role of Relevance in the Interpretation of Verbal Jokes: A Pragmatic Analysis.

Ph.D. thesis. Krakow: Jagiellonian Uiversity, $1991 \mathrm{a}$.

. "What makes a joke tick." UCL Working Papers in Linguistics 3 (1991b): 241-253.

Yus, F. "La teoría de la relevancia y la estrategia humorística de la incongruencia-resolución." Pragmalingüistica 3-4 (1997): 497-508.

\section{Media discourse}

Buckland, W. "Relevance and cognition: Towards a pragmatics of unreliable fïmic narration." Towards a Pragmatics of the Audiovisual. Vol. 2. Ed. J.E. Müller. Münster: Nodus Publikationen, 1995. 55-66.

Forceville, C. "Pictorial metaphor in billboards: Relevance theory perspectives." Towards a Pragmatics of the Audiovisual. Ed. J. Müller. Münster: Nodus Publikationen, 1994. 93-113. 
Pictorial Metaphor in Advertising. London: Routledge, 1996.

Pateman, T. "How is understanding an advertisement possible?" Language, Image, Media. Eds. H. Davis and P. Walton. Oxford: Blackwell, 1983. 187-204.

Ruiz Collantes, F. "Pregnancia, semántica modulada y lectura de imágenes. Cómo un lector determina cuál es la información que vehicula una imagen." Formats 1 (1995). On Internet: $<\mathrm{http}: / /$ www. iua. upf.es/formats/art/a06et.htm> .

Tanaka, K. "The pun in advertising: a pragmatic approach." Lingua 87 (1992): 91-102. . Advertising Language. A Pragmatic Approach to Advertisements in Britain and Japan. London: Routledge, 1994.

Watts, R.J. "Comic strips and theories of communication." Word \& Image 5 (1989): 173-180.

Yus, F. Pragmática y relevancia. Un modelo escripto-icónico aplicado al discurso del cómic inglés (microfilmed edition). Alicante: Servicio de Publicaciones de la Universidad de Alicante. . La interpretación y la imagen de masas. Alicante: Diputación de Alicante, Instituto Juan Gil-Albert, 1997.

"Relevance theory and media discourse: A verbal-visual model of communication." Poetics 25 (1998): 293-309.

\section{Music}

Downes, W. "Pragmatics of music and emotion." Language Forum 2 (1994): 1-27.

\section{Translation}

Guijarro Morales, J.L. "Traduttore traditore? ¡Anda ya!" Pragmalingüística 3-4 (1997): 9-26.

Guillén Galve, I. "Evaluating the appropriateness of a translation. A pragmatic application of relevance theory." Pragmalingüística 3-4 (1997): 27-51.

Gutt, E.-A." Relevance theory and increased accuracy in translation." Notes on Translation 107 (1985): 29-31.

. "Unravelling meaning: An introduction to relevance theory." Notes on Translation 112 (1986a): 10-20. $13-20$.

"Matthew 9:4-17 in the light of relevance theory." Notes on Translation 113 (1986b):

"'What is the meaning we translate?'" Occasional Papers in Translation and Textlinguistics 1 (1987): 31-58.

. "From translation to effective communication." Notes on Translation 2 (1988): 24-40.

"Translation and relevance." UCL Working Papers in Linguistics 1 (1989).

"A theoretical account of translation - without a translation theory." Target 2 (1990):

$135-164$.

Translation and Relevance: Cognition and Context. Oxford: Blackwell, 1991.

Relevance Theory: A Guide to Successful Communication in Translation. Dallas,

Summer Institute of Linguistics, and New York, United Bible Societies, 1992. 
"Relevance: A key to quality assessment in translation." Translation and Meaning, Part 4. Proceedings of the Lodz Session of the 2nd Maastricht-Lodz Duo Colloquium on 'Translation and Meaning.' Eds. B. Lewandowska-Tomaszczyk and M Thelen, 1995. "Implicit information in literary translation: A relevance-theoretic perspective." Target 8 (forthcoming-a): 241-58.

. "Pragmatic aspects of translation: Some relevance-theoretic observations." The

Pragmatics of Translation. Ed. L. Hickey. Clevedon: Multilingual Matters, forthcoming-b.

Hjort-Pedersen, M. "Legal translation and the principle of relevance." Multilingua 15 (1996): 361-371.

Kovacik, I. "Relevance as a factor in subtitling reductions." Teaching Translation and Interpreting.

Vol. II: Insights, Aims, Visions. Eds. C. Dolerup and A. Lindegaard. Amsterdam: John Benjamins, 1994. 245-251.

López folgado, V. "La referencia y la traducción." Pragmalingüistica 3-4 (1997): 63-76.

Mackenzie, I. "Review of Gutt's Translation and Relevance." Journal of Literary Semantics XXIII (1994): 239-244.

Mateo Martínez, J. "La fuerza ilocucionaria y su relevancia en la traducción del inglés al español." Pragmalingüistica 3-4 (1997): 77-88.

Olsen, M.B. "Translated texts and relevance theory: The case of but." Northwestern University Working Papers in Linguistics 4(1992): 57-68.

Pérez González, L. "Pragmatic issues in interlingual and cross-cultural communication: adaptation and manipulation in the translation of García Lorca's Yerma." Pragmalingüística 3-4 (1997): 89-130.

Tirkkonen Condit, S. "A theoretical account of translation: Without translation theory?" Target 4 (1992): 237-45.

Unger, C.J. "Types of implicit information and their roles in translation." Notes on Translation, forthcoming.

\section{Intonation, phonetics, phonology}

Clark, B. and G. Lindsey. "Intonation, grammar and utterance-interpretation." UCL Working Papers in Linguistics 2 (1990): 32-51.

Escandell Vidal, V. "Intonation and procedural encoding: The case of Spanish interrogatives." Current Issues in Relevance Theory. Eds. V. Rouchota and A. Jucker. Amsterdam: John Benjamins, 1998. 169-204.

Fretheim, T. "The effect of intonation on a type of scalar implicature." Journal of Pragmatics 18 (1992): 1-30.

"Intonation and the procedural encoding of attributed thoughts: The case of Norwegian negative interrogatives." Current Issues in Relevance Theory. Eds. V. Rouchota and A. Jucker. Amsterdam: John Benjamins, 1998. 205-236.

House, J. "The relevance of intonation?." UCL Working Papers in Linguistics 1 (1989): 3-17.

Imai, K. "Intonation and relevance." Relevance Theory. Applications and Implications. Eds. R. Carston and S. Uchida. Amsterdam: John Benjamins, 1998. 69-86.

Scheuer, J. "Relevance and prosody in spoken Danish." Journal of Pragmatics 23 (1995): 421-447. Vandepitte, S. "A pragmatic function of intonation." Lingua 79 (1989): 265-297. 


\section{Politeness, face work}

Carretero Lapeyre, M. "The relevance of politeness in the epistemic interpretation of the English modals." Pragmalingüistica 3-4 (1997): 241-259.

Donaldson, S.K. Some Constraints of Consideration on Conversation: Interations of Politeness and Relevance with Grice's Second Maxim of Quantity. Ph.D. Thesis. University of Illinois, 1984.

Escandell Vidal, V. "Cortesía, fórmulas convencionales y estrategias indirectas." Revista Española de Lingüística 25 (1995): 31-66. 629-650.

"Towards a cognitive approach to politeness." Language Sciences 18 (1996):

Gómez Morón, R. "La descortesía no intencionada y el discurso no cortés: El fallo pragmático." The Grove 3 (1997): 33-49.

Jucker, A.H. "The relevance of politeness." Multilingua 7 (1988): 375-384.

Kuiper, K. "The relevance of face calibration." Proceedings of the University of Hertfordshire Relevance Theory Workshop. Ed. M. Groefsema. Chelmsford: Peter Thomas and Associates, 1997. 131-139.

Watts, R.J. "Relevance and relational work: Linguistic politeness as politic behavior." Multilingua 8 (1989): 131-166.

\section{Philosophy, rhetoric}

Campbell, J. L. "The relevant communication of rhetorical arguments." Ph.D. Thesis. Purdue University, 1990.

"An applied relevance theory of the making and understanding of rhetorical arguments." Language \& Communication 12 (1992): 145-155.

Downes, W. "Relevance and the Peircean conception of truth." Proceedings of the University of Hertfordshire Relevance Theory Workshop. Ed. M. Groefsema. Chelmsford: Peter Thomas and Associates, 1997. 28-41.

Sperber, D. and D. Wilson. "Rhetoric and relevance." The Ends of Rhetoric: History, Theory, Practice. Eds. J. Bender and D. Wellbery. Stanford, C. A.: Stanford University Press, 1990. $140-156$.

\section{Speech acts, conversation, interactive particles}

Bird, G.H. "Relevance theory and speech acts." Foundations of Speech Act Theory. Philosophical and Linguistic Perspectives. Ed. S.L. Tsohatzidis. London: Routledge, 1994.

Blakemore, D. "Echo questions: A pragmatic account." Lingua 94 (1994): 197-211.

. "Are apposition markers discourse markers?" Journal of Linguistics 32 (1996): 325-347.

. "The context for so-called discourse markers." The Context in Language Learning and Language Understanding. Eds. K. Malmkjaer and J. Williams. Cambridge: Cambridge University Press, forthcoming. 
Coupland, N. and A. Jaworski. "Relevance, accommodation and conversation: Modeling the social dimension of communication." Multilingua 16 (1997): 233-258.

Cutler, A. "The task of the speaker and the task of the hearer." Behavioral and Brain Sciences 10 (1987): 715-716.

Dominicy, M. and N. Franken. "Speech acts and relevance theory." Speech Act Theory. Eds. D. Vanderveken and S. Kubo. Amsterdam: John Benjamins, forthcoming.

Higashimori, I. "A relevance-theoretic analysis of Huh/Eh." English Literature Review 37 (1993): $83-140$.

Itani, R. "Japanese sentence-final particle tte: a relevance based analysis." International journal of Pragmatics II (1991): 66-75.

"A relevance-based analysis of hearsay particles: Japanese utterance-final tte." UCL Working Papers in Linguistics 6 (1994): 379-400.

. "A relevance-based analysis of Lakoffian hedges. Sort of, a typical and technically."

UCL Working Papers in Linguistics 7 (1995): 87-105.

"A relevance-based analysis of hearsay particles: With special reference to Japanese

sentence-final particle tte." Relevance Theory. Applications and Implications. Eds. R. Carston and S. Uchida. Amsterdam: John Benjamins, 1998. 47-68.

Jucker, A.H. "Irrelevant repetitions: A challenge to relevance theory." Repetition. Ed. A. Fischer. Tubingen: Narr, 1994, 47-60.

Moeschler, J. "Pragmatique conversationelle et pragmatique de la pertinence." Cahiers de Linguistique Française 9 (1988): 65-85.

"Relevance and conversation." Lingua 90 (1993): 149-171.

Théorie Pragmatique et Pragmatique Conversationelle. Paris, Armand Colin, 1996.

Noh, E.-J. "A pragmatic approach to echo questions." UCL Working Papers in Linguistics 7 (1995): 107-140.

Pratt, M.L. "Ideology and speech-act theory." Poetics Today 7 (1986): 59-72.

Tracy, K. "Staying on topic; an explication of conversational relevance." Discourse Processes 7 (1994): 447-464.

Watts, R.J. "Relevance theory and verbal interruptions: Assessing discourse status." Multilingua $16(1997): 153-186$.

Zegarac, V. "What is 'phatic communication'?" Current Issues in Relevance Theory. Eds. V. Rouchota and A. Jucker. Amsterdam: John Benjamins, 1998

\section{Anthropology, ethnography, cross-cultural communication}

Bloch, M. "Language, anthropology and cognitive science." Man 26 (1991): 183-198.

Cameron, R. and J. Williams. "Senténce to ten cents: A case study of relevance and communicative success in nonnative-native speaker interactions in a medical setting." Applied Linguistics 18 (1997): 415-445.

Debray, R. "A plague without fleabites"(on D. Sperber's Explaining Culture). TLS 4918, 4 July 1997, 14-15.

Gerrans, P. "'Is it catching?" (on D. Sperber's Explaining Culture). TLS, 20 June 1997, 4-5. 
Grundy, P. "Relevant to whom: The role of pragmatics in defining linguistic communities." Pragmatic Grammar Components. Ed. F.J. Dols. Tilburg: Tilburg University Press, 1992. 93-115.

Harvey, P. "Relevance theory and anthropology." Liverpool Papers in Language and Discourse 1 (1988): 50-63.

Sperber, D. "Anthropology and psychology: Towards an epidemiology of representations." Man 20 (1985): 73-89.

"The modularity of thought and the epidemiology of representations." Mapping the Mind: Domain Specificity in Cognition and Culture. Eds. L. Hirschfield and S. Gelman. Cambridge: Cambridge University Press, 1994. 39-67. . Explaining Culture. A Naturalistic Approach. Oxford: Blackwell, 1996a.

"Learning to pay attention. How a modular image of the mind can help to explain culture." TLS 4891, 27 December 1996b, 14-15.

\section{Developmental pragmatics}

Foster-Cohen, S.H. "'If you'd like to burn your mouth feel free': A relevance-theoretic account of conditionals used to children." Proceedings of the University of Hertfordshire Relevance Theory Workshop. Ed. M. Groefsema. Chelmsford: Peter Thomas and Associates, 1997. 140148.

Kissç, S. "Issues in developmental "theory of mind" research from the point of view of relevance theory." Proceedings of the University of Hertfordshire Relevance Theory Workshop Ed. M. Groefsema. Cheimsford: Peter Thomas and Associates, 1997. 131-139.

Papafragou, A. "Modality in language development: A reconsideration of the evidence." UCL Working Papers in Linguistics 9 (1997): 77-105.

\section{Communication disorders and limitations}

Clibbens, J. "Relevance theory and augmentative communication." Proceedings of the University of Herffordshire Relevance Theory Workshop. Ed. M. Groefsema. Chelmsford: Peter Thomas and Associates, 1997. 73-77.

Happe, F. "Communicative competence and theory of mind in autism: a test of relevance theory." Cognition 48: 101-119. 